\title{
Tame Economists Need Not Apply: \\ Career Lessons from the 2008 Canadian \\ Association for Health Services and \\ Policy Research Conference
}

\section{Économistes dociles, prière de s'abstenir : leçons de carrière tirées de la Conférence 2008 de l'Association canadienne pour la recherche sur les services et les politiques de la santé}

by CATHERINE L. MAH, MD

Department of Health Policy, Management and Evaluation

Faculty of Medicine, University of Toronto

Toronto, ON

KERRY KULUSKI, MSW

Department of Health Policy, Management and Evaluation

Faculty of Medicine, University of Toronto

Toronto, ON

ELISABETH MARTIN, MA

Département de médecine sociale et préventive

Faculté de médecine, Université Laval

Quebec, QC

STEPHANIE D. SOO, BSC

Department of Health Policy, Management and Evaluation

Faculty of Medicine, University of Toronto

Toronto, ON 
Catherine L. Mah et al.

JILLIAN WATKINS, BASC

Department of Health Policy, Management and Evaluation

Faculty of Medicine, University of Toronto

Toronto, ON

\begin{abstract}
A group of student interviewers sat down with distinguished conference attendees at the 2008 Canadian Association for Health Services and Policy Research Conference. These leaders in the field shared a wealth of advice about career planning (don't), seizing opportunities (do) and connecting with colleagues and community (do often). We learned that a passion for lifelong learning, a willingness to get ordinary things done and a little luck go a long way towards career success.
\end{abstract}

\title{
Résumé
}

Des étudiants ont interrogé d'éminents participants à la Conférence 2008 de l'Association canadienne pour la recherche sur les services et les politiques de la santé. Ces leaders du domaine ont donné de nombreux conseils sur la planification de carrière (ce qu'il faut éviter), sur les occasions à saisir (ce qu'il faut faire) et sur les contacts avec les collègues et la communauté (ce qu'il faut faire souvent). Nous avons appris que la passion pour un apprentissage continu, la volonté d'accomplir des choses ordinaires et un peu de chance sont autant de clés pour une carrière de succès.

"There are three kinds of people in life: those who make things happen, those who watch and describe what happens and those who say, 'What happened?' You want to be in the first category" - Terry Sullivan

7 he CAHSPR Bulletin/Bulletin de l'ACRSPS was a student-run news website at the Canadian Association for Health Services and Policy Research (CAHSPR) conference in Gatineau, Quebec in May 2008. Our production office, nicknamed the "clubhouse," was a small meeting room off the main hallway at the convention centre - a quiet tangle of students, laptop power cords and hotel dishware, where the creation of our publication unfolded amid the bustle of a national conference.

As a complement to our conference coverage, we interviewed five distinguished researchers and decision-makers in the hope of gathering career advice that we could share with fellow trainees and junior researchers. We sat down with: 
- Terry Sullivan, President and Chief Executive Officer (CEO) of Cancer Care Ontario (CCO);

- Claude Castonguay, most recently the Chair of the Quebec Task Force on the Funding of the Health System;

- Evelyn Shapiro, Member of the Order of Canada and 2008 winner of the Emmett Hall Memorial Lectureship;

- Paulette Tremblay, CEO of the National Aboriginal Health Organization; and

- John A. (Jack) Boan, 2006 winner of the Emmett Hall Memorial Lectureship and founder of the Canadian Health Economics Research Association (CHERA), the predecessor association to CAHSPR.

\section{The Role of Chance - and the Importance of Taking Chances}

"We're not going to talk here while your kid is eating a popsicle and I need stamps, so why don't I meet you in your office and we'll talk about it." - Evelyn Shapiro to the Manitoba Deputy Minister of Health in 1974

Our interviewees are all highly accomplished. Their extensive achievements seemed, from a student perspective, to be the product of careful forethought; and yet, serendipity was frequently mentioned as a key component of career success.

Evelyn Shapiro's team established the first provincewide universal home care program in Canada, following an unexpected meeting with the provincial deputy minister of health at a local pharmacy. Shapiro did not commence research in the university setting until her fifties, when she "serendipitously" joined a team of researchers examining the Population Health Research Data Repository in Manitoba - after having raised children and directed social services agencies in Canada and the United States.

Jack Boan, too, claimed that "pure luck and chance" often advanced his career. After completing his doctoral degree, Boan was offered a position with the research team for the landmark 1961 Royal Commission on Health Services with Justice Emmett Hall: a turning point for Boan. When asked about career guidance for students, Boan advised against drafting detailed plans. He recommended aiming for a final professional or doctoral degree, then allowing circumstance and education to guide the way.

Terry Sullivan also described his career trajectory as non-linear and atypical. His work has spanned diverse topics, from child psychology to the Canadian constitution, and diverse settings, including provincial government and the Institute of Work and Health in Ontario. Today, Sullivan is president and CEO of Cancer Care Ontario (CCO), where he reported that there are still no "typical" workdays.

Paulette Tremblay's career has also been filled with myriad pursuits. Her doctorate was in education, but she has worked in a vast range of teaching, counselling, consulting and leadership roles, including service in the US Navy during the Vietnam 
War, school counselling in the Yukon and policy posts with the Canadian federal government. Tremblay's journey has coalesced in her current position as CEO of the National Aboriginal Health Organization.

“Gardez un esprit ouvert! Le passé n'est pas garant de l'avenir: le système de santé est en évolution, le changement est continuel, les technologies évoluent et les défis vont saccentuer. Il faut être en mesure d'ouvrir nos esprits à de nouvelles solutions ...." - Claude Castonguay

Beyond the role of chance, Claude Castonguay suggested that opportunity requires an open mind. Given Castonguay's emblematic history in healthcare and public policy in Canada, his counsel seemed to reflect the magnitude of his task in formulating his February 2008 report, Getting Our Money's Worth: Report of the Task Force on the Funding of the Health System. While some of the report's recommendations have had a mixed reception, Castonguay insists that being open to new solutions, "tout en préservant les valeurs centrales de solidarité et d'équité sur lesquelles repose notre système de santé" ["while preserving the central values of solidarity and equity upon which our healthcare system is built"], is an important lesson for junior researchers.

\section{Get On With It}

"I don't remember having any goal - except to try and handle the problems that were coming my way the best way I could. Is that a goal? I don't know.... I never had any goal like wanting to be prime minister or wanting to be this or that. I just wanted to do what came across my desk." - Jack Boan

Sullivan, Shapiro and Boan urged seizing opportunities as they arrive, in extraordinary circumstances as well as more mundane ones. This entails a lifelong passion for learning, a willingness to try new things and a genuine motivation for getting everyday things done - "delivering the baby", as Sullivan called it. Sullivan continues to find time to teach and do research, despite the rigorous schedule demanded by his position at $\mathrm{CCO}$. He told us that he wants to raise the bar for cancer care quality, even if that means taking a hard and sometimes uncomfortable look at how Ontario sizes up against other health regions, provinces and countries.

Shapiro recalled having to learn statistics in mid-career, her background in statistics having consisted of one course (before the advent of computers). "Sometimes there's something you don't know," Shapiro said, "but somehow you find a way around it." She suggested that a little self-promotion is not a bad thing. "Present yourself as special," she recommended. "Get good references. Get people excited about you." 
Our interviewees have been particularly skilled at identifying gaps and filling them. Boan described the founding of CHERA, now CAHSPR, in the early 1980s. He drafted bylaws, sought out board members and had the organization incorporated. "When I say I got it incorporated," remembered Boan, "I did the work myself! Rather than go through a lawyer and spend $\$ 500$ or $\$ 1,000$. We didn't have any money." Boan's tenacity and fiery resolve has earned him a reputation throughout his career. As a junior researcher, he was approached to study economic effects of the 1950 Red River Valley flood in Manitoba. Boan expressed puzzlement at the offer, proposing that the research could have been conducted by one of many economists available in Ottawa. The chief engineer replied, "Oh, I don't want a tame economist. I want you!"

\section{Remember Where You Came From}

"You need to know who you are and where you come from ... cultural identity shapes who you are." - Paulette Tremblay

All of our interviewees expressed how their achievements have been shaped by vital relationships with colleagues and community. Paulette Tremblay attributes her success to her Mohawk culture, and the relatives, community members and academic associates that she describes as her extended "family" Shapiro, Sullivan and Castonguay conveyed a need to consult colleagues and to incorporate a wide range of stakeholder perspectives in their work. Boan contemplated the memorable influence of individuals such as Justice Hall, "a moral force of considerable dimension."

\section{Building Bridges}

The CAHSPR Conference 2008 theme was "Bridging Silos." Planned half-hour interviews grew into much longer discussions about the many ways to success and fulfillment. In our last interview, Jack Boan regaled us with stories about using punch card tabulating machines, among his lifés lessons. Bridges, it appears, are built one conversation at a time.

\section{ACKNOWLEDGEMENTS}

The authors would sincerely like to thank our interviewees, John A. Boan, Claude Castonguay, Evelyn Shapiro, Terry Sullivan and Paulette Tremblay, for the generous contribution of their time and collected wisdom. We would also like to thank Lillian Bayne, Raisa Deber, Brian Hutchison and Marion Jones for their helpful comments on earlier versions of these interviews, and Kevin Barclay and Sally Clelford for their tireless efforts at the conference on our behalf. Finally, we would like to thank the rest of 
the contributors at the CAHSPR Bulletin for their hard work: Gillian Hanley, Robyn Hastie, Della Kwan, Michael Law, Meghan McMahon and Nelson Shen.

Correspondence may be directed to: Catherine L. Mah, School of Public Policy and Governance, University of Toronto, 14 Queen's Park Crescent West, Toronto, ON M5S 3K9; tel.: 416-9785120; fax: 416-978-5079; e-mail: catherine.mah@utoronto.ca. 